\title{
The Edicts of the Prefect of Egypt The Case of P. Oxy. XXXIV 2704
}

\begin{abstract}
The edicts constituted the most distinguished form of prefectural legal settlements in Egypt. They usually followed the same scheme, which is evident from the edict of Titus Honoratus, published as P. Oxy. XXXIV, 2704. This edict prescribes measures against persons who allow livestock to graze on someone else's field, thereby damaging the crops. The standard edict contains the prescript, followed by the main body of the edict. The date would be stated at the end and it followed the Egyptian calendar. The regulations contained in the exemplary edict are slightly illustrated by two papyri - P. Cair. Isid. 78 and P. Mert. II, 92 which, in particular, sheds light on the provisions governing the penalty contained in the edict. It is still not entirely clear to what situation the edict refers but an analysis of the language used in it and in other documents indicates that it applied to the situation where the humans, rather than the animals, were responsible for damages.
\end{abstract}

It is commonly ${ }^{1}$ known that one of the most important sources of Roman law were the edicts of praetors (an annual declaration of legal principles made by the praetor urbanus²). However, many forget that other Roman magistrates had the power to issue such regulations too. One of them was the prefect of Egypt - praefectus Alexandriae et Aegypti ${ }^{3}$ (called in Greek: ع̌r $\alpha \rho \chi \alpha \varsigma$

\footnotetext{
${ }^{1}$ This article has been prepared as a part of the project titled "The Neighbourhood Law in the Light of Papyri from Greco-Roman Egypt", financed by the National Science Center (NCN) on the basis of the decision $n r$ 2011/03/N/HS3/00936.

2 See e.g. BENNER, The Emperor Says and bibliography cited therein 25, Anm. 2; KRÜGER, Geschichte der Quellen 33-43; WENGER, Quellen 407-424 and literature cited therein.

${ }^{3}$ Generally on the prefects see: JöRDENS, Statthalterliche; REINMUTH, Prefect; and bibliography cited in PURPURA, Gli editti 488-489, Anm. 3.

List of known prefects can be found in BASTIANINI, Lista dei prefetti, with earlier works cited in Anm. 1. List of all sources related to the prefect of Egypt can be found in: BASTIANINI, Il prefetto d'Egitto and BURETH Le préfet d'Égypte.
}

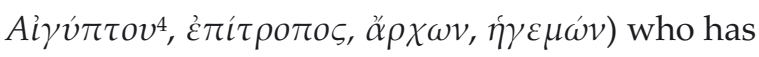
got the ius edicendi from the establishment of the office by Augustus. ${ }^{5}$ A prefect of Egypt had imperium ad similitudinem proconsulis (Ulpian D $1,17,1)$ and was nominated by the Emperor always from among the representatives of the Equestrian rank. ${ }^{6}$

The edicts ${ }^{7}$ constituted the most distinguished form of the prefectural legal settlements in Egypt. $^{8}$ The texts of many edicts of the prefects have been preserved till our times in the papyrological and epigraphical form. We have, accord-

\footnotetext{
${ }^{4}$ About this title see BASTIANINI, "E $\pi \alpha \varrho \chi 0 \varsigma$ Ai $\gamma u ́ \pi \tau o v$ 581-597.

${ }^{5}$ KATZOFF, Sources 809.

${ }^{6}$ REINMUTH, Prefect 1.

${ }^{7}$ With a question of edicts of the prefect of Egypt is strictly related problem of existance, content and character of edictum provinciale and its functioning in Egypt. About this see MARTINI, Ricerche; MoDRZEJEWSKI, Règle de droit; KATZOFF, Provincial Edict ANKUM, La legislation des préfets; ANKUM, Edits des

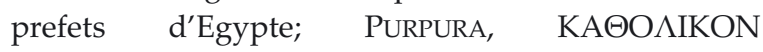
$\triangle$ IATАГМА.

8 JÖRDENS, Erlasse und Edikte 326.
} 
ing to the newest collection of edicts compiled by Gianfranco Purpura, ${ }^{9} 65$ edicts with texts at least partially preserved, which date from the very beginning of Roman ruke over Egypt (the earliest example preserved till our times is dated to the year $4 \mathrm{BC})$, till the $4^{\text {th }}$ century AD.

In the papyrological sources we find edicts of the prefects written only in Greek. ${ }^{10}$ An edictum was known in Greek as a $\delta \iota \alpha ́ \tau \alpha \gamma \mu \alpha^{11}$ (e.g. P. Fouad 10,12 P. Oxy. II, 237; OGIS 665; BGU II, 646; P. Oxy. XLII, 3016, 7) which was a technical term ${ }^{13}$ for it, but there were several other termes which can also refer to edicts - $\check{\varepsilon} \kappa \theta \varepsilon \mu \alpha$ (BGU VII, 1563; OGIS 664), $\quad \pi \rho o ́ \sigma \tau \alpha \gamma \mu \alpha$ (P. Fouad 9; SB XII, 11236), трó $\rho \rho \alpha \mu \alpha$ (PSI XIV, 1406; P. Oxy. I, 34, iv, 6), some times kpíıь (P. Phil. 1, 14) $)^{14}$.

Edicts regulated various matters, some of which were announcements of facts, such as the date of a conventus (P. Ryl. II, 74), census, or accession or removal of emperors (P. Oxy. VII, 1021; P. Amsterdam inv. 22; BGU II, 646, 11-25; BGU XI, 2056). Most of them introduced general rules

\footnotetext{
${ }^{9}$ PURPURA, Gli editti 485-671. List of earlier publications collecting edicts can be found in this publication in Anm. 1.

${ }^{10}$ Chalon, Edict 79; Katzoff, Sources 821; Reinmuth, Prefect 45 .

${ }^{11}$ Katzoff, Sources 819; ReInMUth, Prefect 45; WILCKEN, Edikte 128-33.

12 All papyri are cited according to the Checklist of Editions of Greek, Latin, Demotic and Coptic Papyri, Ostraca and Tablets, available at the following website:

http://library.duke.edu/rubenstein/scriptorium/papyr us/texts/clist_papyri.html. The sigla is followed by volume number in Roman numerals and then by the number of papyrus in Arabic numerals. It can be followed by the line or column number and the date of document. In case of citation of editors comments on the documents the standart sigla is followed by $\mathrm{p}$. - referring to the page number, which distinguishes the latter from the number of document.

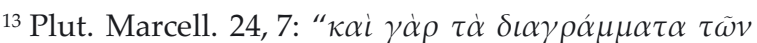

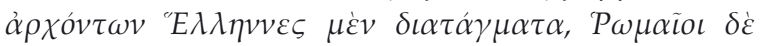
$\dot{\varepsilon} \delta \kappa \tau \alpha \pi \rho о \sigma \alpha \gamma о \rho \varepsilon \dot{v} \sigma \varepsilon \iota . "$

${ }^{14}$ KATZOFF, Sources 819-820.
}

relating to religious matters (P. Fouad. 10), fiscal administration (SB V, 7682), general administration (P. Oslo. III, 79; P. Oxy. II, 237), governmental abuses (eg. P. Lond. III, 1171 verso p. 107), criminal law (P. Haw. 73v; P. Yale inv. 1606), as well as private law and procedure (P. Oxy. XXXIV, 2754). ${ }^{15}$

The external characteristics of edicts were exceptionally uniform and usually followed the same scheme. ${ }^{16}$ These features emerge clearly in the edict of prefect Titus Honoratus from 292 AD, published as P. Oxy. XXXIV, 2704, which prescribes measures against persons who allow livestock to graze on somebody else's field, causing damage to crops. ${ }^{17}$

The English translation of the edict - prposed by the editor - is quoted below: ${ }^{18}$

"Titus Honoratus, the most distinguished prefect of Egypt, says: There would be no profit whatever from our agriculture and the pains taken with it, unless those who regularly spoil crops were to guard against doing this. I learn, in fact, that although the harvest time has produced crops in great abundance, these same herdsmen spoil them. Therefore I enjoin you to guard against allowing beasts in among the crop, (adding) that a lawsuit before my court lies against anyone who disobeys in these matters, so that he shall be deprived of the actual beasts and shall himself experience strong measures. Post.

In the eight year of our lord emperor Diocletian and the seventh year of our lord emperor Maximian. Mecheir $9^{\text {th }} / 9^{\text {th. }}$.

Every edict began with a standard prescript (praescriptio), consisting basically of the phrase: $\delta$

\footnotetext{
${ }^{15}$ KATZOFF, Sources 822.

${ }^{16}$ Katzoff, Sources 820.

17 P. Oxy. XXXIV; p. 87.

${ }^{18}$ I worked on the original Greek text, which can be found in vol. XXIV of the Oxyrynchus papyri and in the internet database of the papyri www.papyri.info.
} 
$\delta \varepsilon \tilde{\imath} v \alpha \lambda \dot{\varepsilon} \gamma \varepsilon \iota$ - so and so says, which corresponds to Latin - dicit, followed by the name of the issuing prefect. This part of the edict was subjected to changes by the addition of new elements. Firstly, during the reign-period of the JulioClaudian dynasty, it consisted solely of name of

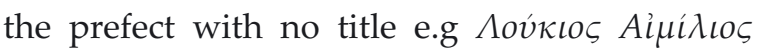

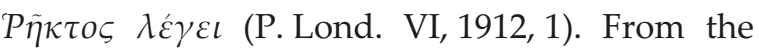
Flavian epoche (the first attestation is P. Oxy. II, 237 from 89 AD) to the end of reign of Gallien, (P. Oxy. XX, 2266, 266-7 AD), the name was followed by the title - prefect of Egypt -

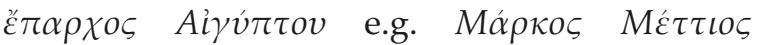

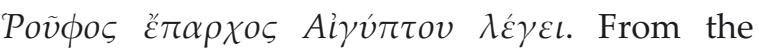
reign of Diocletian (P. Oxy. VI, 888, 287 AD) onwards, an honorific title $\delta \iota \alpha \sigma \eta \mu o ́ \tau \alpha \tau o \varsigma-$ clarissimus, perfectissimus - clearest, purest or $\lambda \alpha \mu \pi \rho o ́ \tau \alpha \tau о \varsigma$ - clarissimus most illustrious, most distinguished were added. ${ }^{19}$ Our document, as dated at the end of the third century, contains the latter praescriptio:

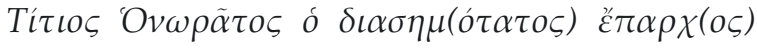

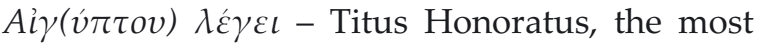
distinguished prefect of Egypt, says.

The prescriptio was followed by the main body of the edict, usually regulating a particular subject or closely related subjects. ${ }^{20}$ This part was preceded by a short preamble where the prefect presented the situation which provoked him to take action, ${ }^{21}$ expressing himself in the first singular person. In our edict, the preamble consists of two sentences, which constitute the essence of the whole text. From this part of the edict we learn that it related to problems resulting from the straying and pasture of animals on crop land. Damages caused by livestock to the crops

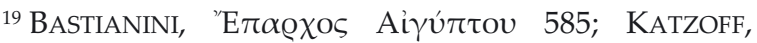
Sources 820; PURPURA, Note introduttive 111; REINMUTH, Praescriptio 24-25.

${ }^{20}$ Chalon, Edict 80; KATZOFF, Sources 820. The only exception is the famous edict of Tiberius Iulius Alexander - very long and concerning many different matters; see CHALON, Edict.

${ }^{21}$ PURPURA, Note introduttive 112.
}

were an age-old problem in agricultural communities in Egypt and the edict of prefects did not constitute the first attempt to regulate this matter. Papyri record numerous cases of damages to the crops caused by animals, either because the animals would wander into neighboring plots or because they would be intentionally driven there by their shepherds. There are a number of statements from Ptolemaic and Roman times concerning the punishment for this offence, dated from the third century BC onward. P. Petrie III, $26^{22}$ ( $3^{\text {rd }}$ century BC) says that if someone's animals trespass and graze on or damage, another man's land, "the owner shall pay to the injured person, in accordance with a legal decision, the amount of the damage done ${ }^{23 "}$. This sort of payment of damages can be seen in a series of petitions e.g. P. Ryl. II, 69 (34 BC), P. Ryl. II, 73 (33-30 BC); PSI IX, 1057 (32 AD); P. Ryl. II, 141 (37 AD). ${ }^{24}$ However, P. Tebt. I, 27, 71-75 (113 BC), stipulated the confiscation of the offending animals. ${ }^{25}$ The difference is perhaps due to the distinction recognized by law ${ }^{26}$ between cases where the person in charge of the animals was directly responsible for the trespass and cases where the animals trespassed onto someone else's land on their own accord. ${ }^{27}$ However, Joseph Modrzejewski suggests, that this points to the general changes in the punishment for such offence.28 In case of damages, the offended party directed a petition to the local authority - to strategus, epistates or later to

\footnotetext{
22 LENGER, Le fragment de loi ptolémaique 459-467.

${ }^{23}$ Translation into English in P. Dub, p. 58.

${ }^{24}$ About this petitions see: TAUBENSCHLAG, Die actio de pastu 567-571. A current list of petitions can be found in: MASCELlaRI, Le petizioni 367-368, 526-527 and Papathomas, P. Heid VII, p. 59-64.

${ }^{25}$ More about this document see TAUBENSCHLAG, Die actio de pastu 568 and ModrzejewSKI, Ulpien et le nature 193.

${ }^{26}$ TAUBENSCHLAG, Die actio de pastu 567-571.

${ }^{27}$ P. Dubl. p. 57-58; TAUBENSCHLAG, Die actio de pastu 567-571.

${ }^{28}$ MODRZEJEWSKI, Ulpien et le nature 193.
} 
the praepositus pagi. An investigation would have been ordered and as a result a report would have been prepared. The legal process would then ensure the punishment was imposed..29

The preamble would have been followed by the substantial part of the edict. This would stipulate the orders, as the prefect would have considered appropriate for the particular situation. The language used in this section would have been severe, authoritative and rigorous. The use of commanding verbs ${ }^{30}$ in the first person ${ }^{31}$ such as $\kappa \varepsilon \lambda \varepsilon \dot{v} \omega$ - to order, $\dot{\varepsilon} \pi \iota \kappa \varepsilon \lambda \varepsilon \dot{v} \sigma \mu \alpha \iota$ - to exhort,

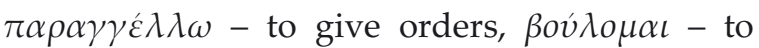
will, wish. ${ }^{32}$ and third person imperatives are common. ${ }^{33}$ The edicts were addressed to the populace at large, with use of general terms of reference such as "let all", "whoever" and "no one". ${ }^{34}$ In P. Oxy. XXXIV, 2704 one can find the

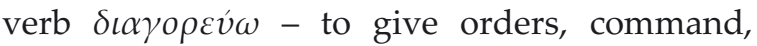
enjoin, ${ }^{35}$ which is not often used in the texts of edicts.

In the example above, the edict merely imposes a requirement to control animals so as to ensure that they do not enter other people's fields. This part of the edict has been concluded by clauses relating to punishment. Naturally, in these clauses, future indicatives were used. What is very interesting, is the fact that such penalties were usually vague and indefinite. ${ }^{36}$ This feature is also evident in our papyrus in which prefect Titus Honoratus reserved lawsuits on such matters to his personal jurisdiction and points that the guilty would have been punished by the confiscation of the offending cattle and other

\footnotetext{
${ }^{29}$ MODRZEJEWSKI, Ulpien et le nature 197.

${ }^{30}$ CHALON, Edict 79-81; KATZOFF, Sources 820; REINMUTH, Prefect 46.

${ }^{31}$ ReInMUTH, Praescriptio 24.

${ }^{32}$ All translations according to LSJ.

${ }^{33}$ KATZOFF, Sources 820.

34 JÖRDENS, Erlasse und Edikte 328.

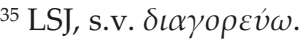

${ }^{36}$ ReINMUTH, Prefect 46; WiLcKen, Edikte 141 Nr. 2.
}

"strong measures". ${ }^{37}$ This provision is rather unclear and enigmatic. Unfortunately we do not dispose of any document related to the problem of the straying of animals, dated directly for the period after enactment of this edict, which might shed some light on those rulings.

We find documents concerning this problem only in year 324 , so it is not entirely clear, if they constitute application of rules prescribed by Titus Honoratus, since it is not excluded that some new regulations were issued in the meantime in regards. ${ }^{38}$ However, it is worth looking closer at them, as they draw some comparison to the edict and often were seen as application of punishments prescribed therein. ${ }^{39}$

These documents are two petitions of Aurelius Isidorus adresses to the praepositus pagi, issued within a short span of time from each other and concerning the problem of damages caused by animals.

The first one - P. Cair. Isid. 78 is a petition to Dioscrus, praepositus of the fifth pagus, from Isidorus, who complained that his crop was damaged by animals grazing in his field, which were put there by an unidentified person. Therefore, he asked the praepositus to initiate the regular procedure. This petition was written on 29 January 324. Four months later, on 3 May, Isidorus addressed another petition to the praepositus - P. Mert. II, 92 where, this time, he included names of the wrongdoers, and lists additional injustice accumulated after that date..$^{40}$

The detailed description of penalties prescribed in these situations, which differ slightly in the two documents, is in context of our edict of particular interest.

Herbert C. Youtie and Arthur E. R. Boak - the editors of P. Cair. Isid., trying to reconcile diver-

37 P. Col. VII, p. 159.

38 JÖRDENS, Statthalterliche Verwaltung 504.

39 P. Cair. Isid. p. 306, P. Dubl. p. 58, Modrzejewski, Ulpien et nature 197-198.

40 P. Cair. Isid., p. 304, 306. 
gent statements contained in those two documents, proposed the following reconstruction of the procedure prescribed in case of damages caused by animals:

"The animals were seized by the landholder whose property had been invaded; they were surrendered by him to the local police, who on receipt of authorization from the praepositus turned them over to an agent of the nome treasury, e.g. exactor; the latter put them up for auction and accepted the price, from which he compensated the landholder to the extent of the damages awarded him, retaining as a minimum for the treasury an amount sufficient to cover the expense of the auction; if the landholders' legitimate claim was not fully met in this way, the offending party was still liable for the remainder." 41

The same editors suggest that the provision relating to the liability for the uncovered part of the damage, could mean that the aggrieved landowner would receive compensation either on the basis of a private agreement or instituting a claim against the former owner of the animals. ${ }^{42}$

Joseph Modrzejewski proposed a slightly different interpretation. According to this author, the sum obtained at the auction served a double purpose: (i) to cover the amount of the fine paid to the treasury, including the costs of the public auction and (ii) to compensate the victim. Since it was possible that little or nothing remained after the payment of the fine, the aggrieved landowner was given the possibility to request redress of damages at the charge of owner of animals - Isidorus clarifies that the right of the owner is protected. ${ }^{43}$

However, Jördens points out that Isidoros not necessarily presented in his petitions reliable

\footnotetext{
${ }^{41}$ P. Cair. Isid., p. 306.

42 P. Cair. Isid., p. 306.

${ }^{43}$ MODRZEJEWSKI, Ulpien et le nature 198.
}

picture of effective regulations, as the versions of penalties depicted by him, seem to depend on scope of his petitions. In the first one, he underlines interests of the state -its possible profit, to motivate officials to take an action which should conduct to detention of persons responsible for damages, who in the moment of presentation of the petition, remained still unknown. In the second one, when wrongdoings were already noted, he indicated first of all, his personal claim, which should be contented by the sale of the animal. A true desire of Isidorus was a compensation for destroyed land and not really care about state interests. Jördens states also that it is difficult to decide, on the bases of those documents, whether owner disposed of some additional means in search of recompense (different then an auction), what seems to be suggested by edict, or not ${ }^{44}$.

It is not entirely clear to what situation the provisions of the edict refers - whether only to damages caused by animals driven onto someone else's plot by their owner or herdsman, or also to damages caused by animals without any human intervention. Editors of the edict and petitions of Aurelius Isidorus do not clarify this point. Editor of P. Dubl. 11, B. C. McGing suggests that it presumably applies to the more serious situation where the humans, rather than the animals were responsible for the damages. ${ }^{45}$ On the other hand, according to Joseph Modrzejewski, the sanction was the same regardless of whether the owner or herdsman brought the animals into the neighboring field with intention to allowing them to graze there, as in case of Isidoros, or whether the animals gained access to the land without any human intervention. ${ }^{46}$

\footnotetext{
44 JÖRDENS, Statthalterliche Verwaltung 505.

${ }^{45}$ P. Dubl., p. 58.

${ }^{46}$ MODRZEJEWSKI, Ulpien et nature 197-198.
} 
The language used in the text is not always easy to interpret but the words of the preamble seem to indicate that it related to cases of intentional destruction of the crops by herdsmen, as in lines 7-8 we find words which directly indicate their illegal actions: "these same herdsmen spoil

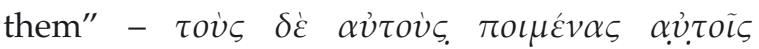
$\lambda v \mu[\alpha i] v \varepsilon \sigma \theta \alpha \iota^{47}$ This interpretation is also supported by the use of the verb $\varepsilon \pi \alpha \phi i \eta \mu$ in the same text $(1,10)$, which means, in relation to animals, "let loose upon/allow them to graze". ${ }^{48}$ This indicates that people took an active role in the offence resulting in damages to crops. Such understanding is reinforced by the use of this verb in other documents. It is normally found in the context of the verb "to pasture" such as $\kappa \alpha \tau \alpha v \varepsilon \dot{\varepsilon} \mu \omega^{49}$ or $\kappa \alpha \tau \alpha \beta \delta \sigma \kappa \kappa \omega^{50}$, which appears, in many petitions related to damages caused by animals as a result of being driven into the fields by their shepherds (P. Köln. III, 140 (244242/219-217 BC); BGU VI, 1251, 10 (155 or 144 BC); P. Wash. Univ. II, 77 = P. Vind. Worp. 2, 10 (21 BC); SB XX, 14098, 9 (1-10 AD); BGU III, 757, 7 (12 AD); P. Oslo. III, 123, 14 (22 AD); SB XIV, 11335, 14 (26 AD); P. Ryl. II, 126, 14 (28/9 AD); P. Ryl. II, 138, 7 (34 AD); P. Ryl. II, 143, 10 (38 AD); P. Ryl. 147, 17 (39 AD); P. Ryl. 149, 13 (39/40 AD); P. Ryl. II, 152, 4 (42 AD); P. Strasb. IV, 181, 10 (166 AD), P. Mert. II, 92, 9, 6). The same word is used in the above mentioned

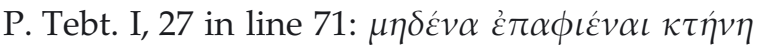

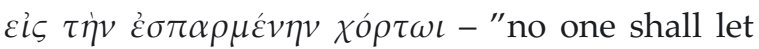
loose animals upon land sown with grass." 51 This points out, that edict was intended to apply rather to cases of intentional illegal pasturing on someone else's land and no to situations where animals entered neighboring ground by them-

\footnotetext{
${ }^{47}$ The verb $\lambda v \mu \alpha i v o \mu \alpha \iota$ means spoil, ruin, injure, cause damage.

${ }^{48}$ LSJ, s.v. Ėं $\alpha \phi i ́ \eta \mu$.

${ }^{49} \mathrm{LSJ}$ - to graze.

${ }^{50} \mathrm{LSJ}$ - to feed upon.

51 Translation of the editors.
}

selves. This latter circumstance was usually described in petitions by the sentence including the verb $\varepsilon \dot{v} \rho i \sigma \kappa \omega$ followed by $\kappa \alpha \tau \alpha \beta \delta \sigma \kappa \varepsilon \iota v$ or $\kappa \alpha \tau \alpha \nu \varepsilon^{\prime} \mu \omega-$ - I found (animals) pasturing". This interpretation of the provisions contained in the edict would explain the severity of the punishment, in respect of which one notes a certain element of continuity since Ptolemaic times. Indeed the punishment imposed would generally result in the confiscation of the offending animal, as was also prescribed in P. Tebt. I, 27. However, it is not excluded that in case of unassisted wandering of animals only compensation of the damages would have been prescribed. Unfortunately we do not have any example of petitions applicable to this situation after the enactment of the edict.

The main body of edict ends without any greeting word. ${ }^{52}$ At this point in several edicts, including our example, just before the date, there would be the term $\pi \rho \circ \tau \varepsilon \theta \eta \tau \omega$ "let this be posted" (P. Oxy. XXXVI, 2754, 13 (111 AD); P. Oxy. I, 34, ii, 16 (127 AD); P. Oxy. I, 34, iii, 14 (127 $\mathrm{AD}) ; \mathrm{BGU}$ I, 288, 11 (144-147 AD) or $\pi \rho o ́ \theta \varepsilon \varsigma$ "post" (P. Oxy. XXXVI, 2704, 14). This phrase was not addressed to local officials requiring public distribution, but to the prefect's clerical staff and it functions as an authorization to release the document, rather than an order for posting 53

The date according to the Egyptian calendar is given at the end and would state the year of the reigning emperor and the day of the Egyptian month. ${ }^{54}$

If we assume that the petitions of Isidours are examples of the application of the rules contained in the prefectural edict from 292, we would have here another example of a characteristic feature of the prefectural edict in Egypt,

\footnotetext{
52 KATZOFF, Sources 820.

${ }^{53}$ KATZOFF, Letters and edicts 212.

${ }^{54}$ Chalon, Edict 79; KATZOFF, Sources 821.
} 
namely its permanent validity. ${ }^{55}$ This quality is confirmed by the citations in courts of edicts many years after they were promulgated. ${ }^{56} \mathrm{~A}$ good example of this phenomenon is P. Oxy. VI, $899=$ W. Chr. 361 (200), ${ }^{57}$ where during the trial in 154, there is a quotation from an otherwise unknown edict of the prefect Tiberius Iulius Alexander dated in 69. Therefore, the edict would have been considered to be valid, 85 years after its issue. In the case of our edict it would have been considered to be valid 32 years after its enactment.

P. Oxy. XXXIV, 2704 illustrates all the characteristic features of the prefectural edicts in Egypt. In addition it enables us to examine its probable practical application, thanks to petitions drawn up a few decades after its enactment, dealing with the problem regulated therein. It shows also continuity, vitality but also prosaism of problems regulating in such acts of the prefects.

\section{Korrespondenz:}

Aneta Skalec

Department of Roman and Antique Law

Faculty of Law and Administration,

University of Warsaw

Ul. Krakowskie Przedmieście 26/28,

00-927 Warszawa, Poland

anetaskalec@gmail.com

\section{Abkürzungen:}

BGU

LSJ
Ägyptische Urkunden aus den Museen zu Berlin: Griechische Urkunden (Berlin 1895ff)

Henry G. LIDDELL, Robert SCOTT, A Greek-English Lexicon (Oxford 91996).

\footnotetext{
${ }^{55}$ KATZOFF, Sources 823; KATZOFF, Validity 46; WILCKEN, Edikte 140-144.

${ }^{56}$ KATZOFF, Sources 823.

${ }^{57}$ More about this papyrus KATZOFF, Validity 46.
}

OGIS Wilhelm DitTENBERGER (Hg.), Orientis Graeci inscriptiones selectae (Leipzig 1903-1905).

P. Amsterdam R.P. SALOMONS, P.J. SIJPESTEIJN, K.A. WORP (Hgg.), Die Amsterdamer Papyri (Zutphen 1980).

P. Cair. Isid. A.E.R. BOAK and H.C. YOUTIE (Hgg.), The Archive of Aurelius Isidorus in the Egyptian Museum, Cairo, and the University of Michigan (Ann Arbor 1960).

P. Col. Columbia Papyri. 11 Bde. (New York-Atlanta 1929-1998).

P. Dubl. $\quad$ B.C. McGING (Hg.), Greek Papyri from Dublin (Bonn 1995).

P. Fouad A. BAtAille u.a. (Hgg.), Les Papyrus Fouad I (Cairo 1939).

P. Lond. Greek Papyri in the British Museum (London 1893-1974).

P. Mert. A Descriptive Catalogue of the Greek Papyri in the Collection of Wilfred Merton, 3 Bde. (LondonDublin 1948-1967).

P. Oslo. Papyri Osloenses (Oslo 1925-1936).

P. Oxy. The Oxyrhynchus Papyri, 75 Bde. (London 1898-2010).

P. Petrie J.P. MAhaffy, J.G. SMyly (Hgg.), The Flinders Petrie Papyri (Dublin 1891-1905).

P. Phil. J. Scherer (Hg.) Papyrus de Philadelphie (Cairo 1947).

P. Ryl. Catalogue of the Greek and Latin Papyri in the John Rylands Library, Manchester, 4 Bde. (Manchester 1911-1952).

P. Strasb. Griechische Papyrus der Kaiserlichen Universitäts- und Landesbibliothek zu Strassburg, 9 Bde. (Leipzig-Strasbourg 1912-1989).

P. Tebt. The Tebtunis Papyri, 5 Bde. (London 1902-2005).

P. Vind. Worp. K.A. WORP (Hg.), Einige Wiener Papyri (Amsterdam 1972).

P. Wash. Univ. Washington University Papyri, 2 Bde. (Missoula-Opladen 19801990).

P. Yale Yale Papyri in the Beinecke Rare Book and Manuscript Library, 3 Bde, (New Haven u.a. 1967-2001).

PSI Papiri greci e latini; 15 Bde. (Firenze 1912-2008). 
SB

Sammelbuch griechischer Urkunden aus Aegypten, 26 Bde (Strassburg u.a. 1915-2006).

W. Chr.

L. MitTeIS, U. WiLCKeN, Grundzüge und Chrestomathie der Papyruskunde, Bd. I: Historischer Teil, II. Hälfte: Chrestomathie (LeipzigBerlin 1912).

\section{Literatur:}

Hans ANKUM, La legislation des préfets d'Egypte et l'edictum provinciale, in: ANAMNHCIC (Gehnt 1970) 63-69.

Hans ANKUM, Les edits des prefets d'Egypte et le probleme de l'édictum provinciale, in: Annales de la Faculté de Droit et des Sciences Economiques de Toulouse 18 (1970) 357-364.

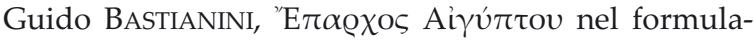
rio dei documenti da Augusto a Diocleziano, in: ANRW, Bd. II, 10.1 (1988) 581-597.

Guido BASTIANINI, Il prefetto d'Egitto (30 a. C. - 297 d. C.): Addenda (1973-1985), in: ANRW, Bd. II, 10.1 (1988) 503-517.

Guido BASTIANINI, Lista dei prefetti d'Egitto dal 30ª al 299p, in: Zeitschrift für Papyrologie und Epigraphik 17 (1975) 263-328.

Margareta BENNER, The Emperor Says. Studies in the Rhetorical Style in Edicts of the Early Empire (Göteborg 1975).

Paul Bureth, Le préfet d'Égypte (30 av. J. C. - 297 ap. J.C.). Etat présent de la documentation en 1973, in: ANRW, Bd. II, 10.1 (1988) 472-502.

Gerard Chalon, L'Edit de Tiberius Julius Alexander, étude historique et exegetique (Olten-Lausanne 1964).

Andrea JÖRDENS, Erlasse und Edikte. Ein neuer Erlaß des Präfekten M. Sempronius Liberalis und die Frage der statthalterlichen Rechtsetzungkompetenz, in: Symposion 1995, Vorträge zur griechischen und hellenistischen Rechtsgeschichte KölnWeimar-Wien 1997) 325-352.

Andrea JÖRDENS, Statthalterliche Verwaltung in der römischen Kaiserzeit. Studien zum praefectus Aegypti (Stuttgart 2009).

Katzoff, The Provincial Edict in Egypt, in: Tijdschrift voor Rechtsgeschiedenis 37 (1969) 415-437.

Ranon KATZOFF, Prefectural edicts and letters, in: Zeitschrift für Papyrologie und Epigraphik 48 (1982) 209-217.
Ranon KATZOFF, Sources of Law in Roman Egypt: The Role of the Prefect, in: ANRW, Bd. II, 13 (1980) 810-844.

Ranon Katzoff, The Validity of Prefectural Edicts in Roman Egypt, in: Bar-Ilan Studies in History (Ramat Gan 1978) 45-53.

Paul KRÜGER, Geschichte der Quellen und Litteratur des Römischen Rechts, (München-Leipzig 21912).

Marie-Thérèse LENGER, Le fragment de loi ptolémaique P. Petrie III, 26 (Bodl. Ms. Gr. class. d 27 [p]), in: Studi in onore di U. E. Paoli (Firenze 1955) 459-467.

Remo MARTINI, Ricerche in tema di editto provinciale, Milano 1964.

Roberto MASCELLARI, Le petizioni nell'Egitto romano. Evoluzione di formulario, procedure e organizzazione della giustizia. Documentazione su papiro dal 30 a.C. al 200 d.C. (Ph.D., Univ. Firenze 2012).

Joseph MODRZEJEWSKI, La règle de droit dans l'Égypte romain, in: Proceedings of the XII International Congress of Papyrology (Toronto 1970) 341-344.

Joseph MeLEZE ModrzejewSKI, Ulpien et la nature des animaux, in: Droit impérial et traditions locales dans l'Egypte romaine (Aldershot 1990) 177-199.

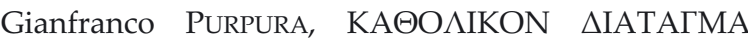
(sulla denominazione dell'editto provinciale egizio), in: Studi in onore di Arnaldo Biscardi, Bd. II (Milano 1982) 507-23.

Gianfranco PurpurA, Gli editti dei prefetti d'Egitto I sec. A. C. - I sec. d. C., in: Annali del Seminario Giuridico della Università di Palermo 42 (1992) 485-671.

Gianfranco PURPURA, Note introduttive allo studio del linguaggio del prefetto d'Egitto, in: Minima Epigraphica et Papyrologica 1 (1998) 109-115.

Oscar William ReINMUTH, The Prefect of Egypt from August to Diocletian, Klio 34 (Leipzig 1935).

Oscar William ReINMUTH, The prefectural edict. I The praescriptio, in: Aegyptus 18 (1938) 3-28.

Rawał TAUBENSCHLAG, Die actio de pastu, de pauperie und de arboribus caesis im Rechte der Papyri, in: Archiv Orientalni 20 (1952) 65-68 = Ders.; Opera Minora Bd. II (Warszawa 1959) 567-571.

Leopold WENGER, Die Quellen des römischen Rechts (Wien 1953).

Ulrich WILCKEN, Zu den Edikten, in: ZRG RA 42 (1921) 124-158. 